\title{
The Secreted Curriculum and Youth Education to Become the Professionals the World Craves for
}

\author{
Dinah Katindi Nyamai*
}

* University of Nairobi, Nairobi, Kenya

E-mail: dinah.nyamai@aiu.ac.ke

\section{Article Info}

Received: February 16, 2021

Revised: May 11, 2021

Accepted: June 24, 2021

$10.46303 / j c s r .2021 .10$

\section{How to cite}

Nyamai, D.K. (2021). The Secreted Curriculum and Youth Education to Become the Professionals the World Craves for. Journal of Curriculum Studies Research, 3(2), pp. 169-193. https://doi.org/10.46303/jcsr.2021.10

\section{Copyright license}

This is an Open Access article distributed under the terms of the Creative Commons Attribution 4.0 International license.

https://creativecommons.org/licenses/by/4.0/

\section{ABSTRACT}

Societies have always recognized the need for nurturing children to not only become intellectually smart but also morally upright professionals. While factors pertaining to professionalism education include the environment, there seems to be limited awareness of the importance of creating holistically enriching learning contexts. This article sought to determine the role played by accidental lessons arising from the secreted curriculum on youths' ways of thinking and behavior among 1246 young people in Christian universities in Nairobi County. The researcher begun with a quantitative phase and followed with a qualitative phase on major findings to provide indepth understanding on the initial results. Yamane's sample size calculation formula, which is given by $\mathrm{n}=\mathrm{N} /\left(\right.$ one $\left.+\mathrm{Ne}^{\wedge} 2\right)$ : where $\mathrm{n}=$ corrected sample size $\mathrm{N}=$ population size, and $\mathrm{e}=$ margin of error (MoE), e=0.05, was employed in determining the sample size, which gave 486. The self-developed questionnaire with 64 items and an interview guide with 14 items were used. The SPSS statistical program version 25 was used in analyzing data. The results indicated that lessons arising from the secreted curriculum shape youth's ways of thinking and behaviour either negatively or positively.

\section{KEYWORDS}

Professionalism; moral values; education; secreted curriculum; youth. 


\section{INTRODUCTION}

Education has always been a trilogy: acquisition of professional skills, transmission of relevant knowledge, and inculcation of desirable values and attitudes. This means children, present and future leaders, not only require valuable information but holistic transformation-fostering the whole person: the psychomotor, cognition, intelligence, attitude, and behaviour (Vazhathodi, 2013). Some years ago, Aristotle, one of the greatest Western intellectual figures, asserted that "educating the mind without educating the heart is no education at all" [cited by Pasha, 2018, p.3]. In the same vein, Mahatma Gandhi (cited by Covey, 1990) posited that pure "intellectual development without commensurate internal character development makes as much sense as putting a high-powered sports car in the hands of a teenager who is high on drugs" (pp. 87-93). A positive learning atmosphere is an indispensable component of holistic nurture (Verma, 2019). Learning contexts that holistically nurture young people to become the kind of people the world craves for-people who can positively change unwholesome moral situations, are described as reinforcing behaviours that benefit not only the individual but the world. MerriamWebster "defines craving as an intense, urgent, or abnormal desire or longing (a great want)." H.L. Hastings, author of "Sold Cheap" in 1866, [cited in Kevin Morgan, 2017], asserted:

The great want of 'this' age is men-men who are not for sale-men who are honesty to the bottom - sound from centre to circumference, true to the hearts core. Men that fear the Lord and hate covetousness. Men who will condemn wrong in a friend or foe, in themselves as well as in others. Men whose conscience are steady as the needle to the pole. Men who will stand for right if the heavens titter and the earth reels. Men who will tell the truth and look the world and the devil right in the eye. Men who neither swagger nor flinch. Men who can have courage without whistling for it and joy without shouting to bring it. Men in whom the current of everlasting life runs still and deep and strong. Men careful of God's honour and careless of men's applause. Men too large for sectarian limits and too strong for sectarian bounds. Men who do not strive nor cry, nor cause their voices to be heard in the streets, but will not fail, nor be discouraged till judgement be send in the earth... Men who know their message and tell it-men know their duty and do it-men who know their place and fill it-men who mind their own business. Men who will not lie. Men who are not too lazy to work, nor too proud to be poor. Men who are willing to eat what they have earned and wear what they have paid for. Men who are not ashamed to say 'no' with emphasis, and who are not ashamed to say, 'I can't afford it'... (p.1)

These worthwhile attitudes, values and virtues are mostly nurtured in learning institutions where curriculum implementers not only teach students' mind but also create learning environments that foster development of students' affective domain. According to Habibu (2020) and Parihar et al. (2018), learning institutions cannot be solely blamed for dwindling numbers of morally upright professionals - people who maintain high decorum even when no one is watching, but young people spend much of their formative years in learning 
institutions-close to 900 hours a year (Rowland, 2014), more than the time they spend in any other social context, which significantly shape their work ethic, emotions, intellect, behaviour, and professional identity. Verma (2019) suggested that the process of acquiring moral behaviour becomes something that young people easily adapt to in conducive learning environments. Fyock (2008) and Drew (2021) echoed the same sentiments when they claimed that young people do not attend learning institutions in a vacuum: they gather in varied forums where they unconsciously pick messages regarding how to behave and interact with the world. Chowdhury (2016), [citing Reiss, 1999] claimed that "people do not live their lives in moral isolation but grow up within certain moral traditions" (p.1), which shape their behaviour in both positive and negative ways. As noted by Dewey (1938), "perhaps the greatest of all pedagogical fallacies is the notion that a person learns only the thing he or she is studying at the time. Collateral learning in the way of formation of enduring attitudes, of likes and dislikes, may be and often is much more important than oral spelling lessons or a lesson in geography" (p. 20).

A good number of learning institutions however do not pay close attention to creating conducive learning environments to promote students' acquisition of non-cognitive skills and upright character values like professionalism. Sager (2013) for example bemoaned formalized pure intellectual teaching-learning processes in learning contexts yet professionalism, like any other professionalism is more caught than taught-majorly reinforced and stabilized by accidental messages arising from casual interactions and non-verbal communications (Drew, 2021; Hafferty \& Franks, 1994; Lempp \& Seale, 2004). Crossman (2019), Barani et al. (2011), Çubukçu (2012), Massialas and Joseph (2009) and Yousefzadeh (2014) concurred in that influences of the secreted curriculum on young people's ways of thinking, and behaviour is equal to or are even greater than influences of the overt curriculum. According to Lempp and Seale (2004), some of the secreted curriculum consequences include "loss of idealism, adoption of a 'ritualized' professional identity, emotional neutralization, change of ethical integrity and acceptance of hierarchy" (p. 770). Other negative consequences of the secreted curriculum included weakening of moral reasoning among young people (Patenaude et al., 2003; Doja et al., 2018).

The unrestrained sleaziness and dishonesty permeating almost every facet of our societies rekindles concerns about the role of educational systems in the holistic nurture of young people. Such moral hitches can be likened to what Song of Solomon in 2:15 called 'small foxes' that were threatening thriving vineyards which represented the budding love affair between Solomon and his Shulammite, bride-to-be. The phrase 'little foxes' suggest that the creatures were tiny, but though not as strong as a bull or an elephant that can trample down whole vineyards in just an hour, the tiny creatures did terrible damage-they burrowed and chewed a vineyard until the vines withered and become totally unproductive. The tiny creature can also be likened with small landmines buried beneath the surface which only detonates when somebody steps on them or an automobile drives over them. A small land mine may not really seem all that dangerous but of all the armaments nations across the globe have amassed over 
their years of combat, few are as dangerous to young people as land mines. Thousands of young people planting crops in their parents' farms, herding their parents' animals, or just playing, have been maimed or even killed by the deadly devices. Like the alluded environmental hitches, some secreted lessons arising from social learning contexts, which are often "accepted as status quo, even when they contribute to undesirable behaviours" (Howieson \& Cloke, 2019, p. 1), if not identified and 'rounded up', they will hinder or destroy that which is of value-the holistic nurture of young people to be the kind of people the world craves for.

The question then begs is the role played by the secreted curriculum usually taken into consideration during the design and launch of every new curriculum? The word 'role' may seem to indicate that the researcher will pinpoint exactly how and through which mechanisms the secreted curriculum is involved in holistic professional values nurture, but the researcher does not claim to specify every causal relationship between young people's acquisition of holistic professional values. The researcher rather, uses the word to emphasize her belief in that accidental messages conveyed through the secreted curriculum play an important role in the acquisition of holistic professional values and upright character among young people. The researcher believes minimizing negative aspects of the secreted curriculum while maximizing its positive elements is likely to create emotionally secure environments that facilitate acquisition of holistic professional values like integrity, trustworthiness, commitment to excellence, respect for human dignity, and compassion. At the end, the researcher will suggest strategies for utilizing positive aspects of the secreted curriculum in holistic professional education. The quantitative phase of current research sought to test the following five pertinent null hypotheses:

- $\mathrm{H}_{01}$ : There is no significant relationships between students' demographics and their perceptions regarding how accidental lessons arising from the secreted curriculum influences their ways of thinking and behaviour.

- $\mathrm{H}_{02}$ : There is no significant relationship between unintended lessons arising from learning institutions' organizational structure and students' ways of thinking and behaviour.

- $\mathrm{H}_{03}$ : There is no significant relationship between unintended lessons arising from learning institutions' social interrelationships and students' ways of thinking and behaviour.

- $\mathrm{H}_{04}$ : There are no significant differences between influences of accidental lessons arising from learning institutions' on-ground and accidental lessons arising from online instructional models on students' ways of thinning and behaviour.

- $\mathrm{H}_{05}$ : There is no significant relationship between unintended lessons arising from learning institution' cultural orientations and students' ways of thinking and behaviour. 
The qualitative phase of current research explored in-depth why selected respondents thought some elements of the secreted curriculum, tested in the quantitative phase, were perceived as having more significant influences on students' ways of thinking and behaviour, than others did.

\section{The Concept of Secreted Curriculum and Professional Skills}

The concept of a hidden or secreted curriculum was coined by Phillip Jackson in 1968. The emphasis here is that students learn a social curriculum evolving from social interrelationships in learning contexts, including dispositions, values, and behavioural expectations like learning to exercise restraint, being patient, completing class assignments properly and within set time, keeping oneself busy, collaborating with other students, being well-ordered and on time as well as conducting oneself politely (as cited in Roig-DeBellis, 2014). While a comprehensive official curriculum can empower learners to be inquirers, and real leaders of their personal learning, the secreted curriculum is more pervasive, and more powerful in shaping young people's attitudes, ways of thinking, and their professional identity compered to any prescriptions in lecture rooms (Glicken \& Merenstein, 2009; Howieson \& Cloke, 2019; Hafferty \& Ronald,1994;). Observing how other professionals do what they do and say what they say powerfully inculcate values and professional skills that last the entire life of young people (Bayramlı, 2018; Killick, 2016). These sentiments are echoed by Rogers et al. (2012), Safari et al. (2020) and Abroampa (2020) when they claimed that there existed a substantial influence of the secreted curriculum on the development of professionalism of medical students. Abroampa (2020) asserted that the hidden curriculum:

[...] is responsible for as much as ninety percent (90\%) of all learning taking place in school. It may therefore be posited that learners learn more than they are taught. The implication then is that a huge chunk of what learners consume unintentionally $(90 \%)$ in any school environment, be they worthy or unworthy, happens on the blind side of the school and not under careful control since schools, policy makers and parents are interested in what learners have been taught and how it manifests in their grades. ( $p$. 71)

A secreted curriculum is always experienced in every teaching-learning milieu albeit in varying degrees (Hafferty et al. 2015; Ruff, 2013), and its negative elements can lead to professional ethical erosion if left unaddressed (Hundert et al.,1996; Patenaude et al. 2003). Even though influences of accidental lessons arising from the secreted curriculum on students' learning experiences are enormous, educators often focus on the cognitive component of the official curriculum (Priestley, 2019, p. 1).

Learning contexts encompass an enormous diversity of social, intellectual, structural, cultural, and environmental factors that have a potential of generating a secreted curriculum, but this article was not able to extensively catalog all of them. Yousefzadeh (2014) among other scholars however identified four key aspects: architecture, student-instructor interrelationships, instructional model, and cultural inclinations. This observation was echoed 
by Safari et al. (2020), which identified similar learning institutions' places and activities that embody a secreted curriculum. They include learning institutions' organizational structure (architecture), student-instructor interrelationships, instructional models employed by instructors, and learning institutions' cultural orientations.

The way in which a learning context is organized communicates unintended lessons to students which have a potential of shaping their ways of thinking either positively or negatively. For example, a rectangular classroom organization with the instructor mainly stationed in front of the class, can have negative effects on students' sense of belonging, self-worth, and their potential in academic tasks (Shaw, 2006). According to Eisner (2002), what learning institutions choose to teach and what they leave out tells students what is most important in their life. Even when a certain subject matter is entirely taught, what instructors choose to examine, and what they leave out communicate to students what is important to learn and what is of little value in that field of study. In addition, the ways in which learning institutions' members interact with students and say what they say and do what they do significantly determines the kind of people students turn out to become irrespective of their gender, age, and mental aptitude. The accidental messages arising from the values and attitude instructors bring to their relationships with students gradually influence students' values, attitude, knowledge acquisition styles, their ways of thinking and behaviour.

Other non-academic features of meta-learning contexts like learning institutions' dispositions (cultural inclinations) also present a culture that embodies educational ideologies encapsulated in common metaphors learning institutions use such as "we produce-to describe educational purposes which portray students as raw materials to be processed. This observation is in line Donohue (2021) who claimed that people's "culture influences the goals people set, why they set such goals, and the degree of motivation they put forth to achieve those goals" ( $p$. 1). Yüksel (2006) and Chandratilake \& de Silva (2009) pointed at deep sociological implications conveyed through learning institutions' cultural inclinations which significantly shape the ways in which students come to perceive themselves. However, as noted by Garcia (2014) most of the existing structures in some learning instructions are at odds with the holistic nurture of young people-that is inculcation of worthwhile attitudes, values, and other non-cognitive skills. Some accidental lessons arising from some learning institutions' secreted curriculum shape young people's professional identity negatively (Çubukçu, 2012; Crossman, 2019; Fyock, 2008; Killick, 2016), but mostly curriculum designers and implementers rarely think about it during curriculum reforms.

The researcher in this article frequently uses the terms: "profession-a distinct category of occupational work," second, professionalization - "the process in which a professional group develops, pursues, obtains and maintains key characteristics of a profession" and third, "professionalism - the conduct, qualities, moral standards or aims that characterize or guide professionals' work ethics," as defined by Evetts (2009, p. 3-7), among other scholars. Based on these definitions, a professional is a person belonging to a certain profession while 
professionalism is the character, status or skills expected of a professional such as discretion, reliability, even-handedness, compassion, and fair play. These definitions are echoed by dictionaries like the Merriam-Webster's Collegiate Dictionary (2002) which defines professionalism as the aims, conduct, or abilities that mark or characterize a professional person or a profession. Researchers like Vivanco and Delgado-Bolton (2015) suggested that "given its universal nature, professionalism is not only global in its reach, covering the different geographical and cultural realities where the medical profession is practiced, but its timeless dimension makes it present at all stages of professional life" (p.7). Porcupile (2015), Vivanco and Delgado-Bolton (2015 and Raghubir, 2018, among other researchers, suggested several professionalism attributes that define truly professional people as briefly discussed in the following short paragraphs:

Specialized Knowledge: True professionals are known for their specialized knowledge (Porcupile, 2015). They are commitment to developing and improving their professional skills and specialize in needed areas which makes them succeed in their fields and keep knowledge of their field up to date, so that they can continue to deliver the best work possible.

Competency: True professionals ensure jobs are thoroughly done. Even when circumstances arise that prevent them from delivering on their promises, they do not make excuses about their failures. They focus on finding solutions and do their best to make the situation right (Porcupile, 2015; Vivanco \& Delgado-Bolton, 2015).

Honesty and Integrity: Truly professional people endeavour to do the right thing, even when it means taking a harder road. They exhibit honesty and integrity. They are humble and not afraid to admit that a certain job falls outside their scope of expertise (Porcupile, 2015).

Accountability: True professionals hold themselves accountable for their words, thoughts, and actions, especially when they make mistakes. The personal accountability is closely tied to honesty and integrity, and it is the most vital element in true professionalism (Vivanco \& Delgado-Bolton, 2015).

Self-Regulation: True professionals remain professional even when dealing with irate clients. Instead of getting irrational, they exhibit true professionalism by maintaining a calm, demeanour, and by doing everything that they can to make the situation right (Porcupile, 2015). They show respect for the people around them, no matter their rank as well as exhibit a high degree of emotional intelligence.

Emotional Intelligence: True professionals manage their emotions and are clearly aware of other people's feelings. Professionalism requires one to keep his or her emotions in check but at other times it requires one to express his or her feelings so as to have meaningful conversation or to stand up for what one believes in (Raghubir, 2018).

Compassion/humanism: Compassion/empathy is the common ground where the ethical teachings of all major traditions, religions, and humanitarianism, come together and it is the true mark of truly professional people (Vivanco \& Delgado-Bolton, 2015). 
Image: True professionals do not show up to work sloppily dressed or with unkempt hair (Porcupile, 2015). They dress appropriately for the situation and because of this, they exude an air of confidence as well as gain respect.

Even though investigations on the term professionalism and related terms like profession and professionalization have a long-standing tradition in sociological research, "current employees lack soft skills like professionalism significantly" (Denisov, 2017, p. 1) as employers continue to witness young people (present and tomorrow's leaders), struggle with constructive criticism, acknowledgement of failure, and amending errors while others do the bare minimum to accomplish assigned tasks. This article describes the role played by holistically nurturing environments in nurturing truly professional behaviour.

\section{METHODS}

In this research mixed research method was adopted. According to Shorten and Smith (2017), this is a research method whereby investigators gather and analyses both qualitative and quantitative data within the same research.

\section{Design}

In order to minimize limitations of either research approach, the researcher employed a sequential explanatory design. In the quantitative first phase, the researcher collected and analysed data from 486 responded about the secreted curriculum, which informed the followup qualitative second phase to explain and enrich the quantitative data as suggested by Creswell \& Clark (2011) and Hubbard (2010). The researcher went through the filled closed-ended questionnaires to identify factors tested in first phase that respondents had perceived as having significant (strongly agree) or not having significant (strongly disagree) influence on their ways of thinking and used them to develop an interview guide with 14 open-ended items to gather in-depth explanations through face-to-face interviews with 10 key informants.

\section{Research Population}

The population of the research was 1246 undergraduate students in Christian universities in Nairobi City County. The researcher employed Taro Yamane's sample size calculation formula. The formula is given by $n=N /\left[1+N\left(e^{\wedge 2}\right)\right]$ : where $n=$ corrected sample size, $N=$ population size, and $\mathrm{e}=$ Margin of error $(\mathrm{MoE}), \mathrm{e}=0.05$. Hence at $5 \% \mathrm{MoE}$., the sample size from Africa International University was $680\left(1+680\left(0.05^{\wedge} 2\right)=680 / 2.7=251.85^{\sim} 252\right.$ while from Kenya Methodist University was 566/ $\left(1+566\left(0.05^{\wedge} 2\right)=566 / 2.42=233.884^{\sim} 234-\right.$ a total of 486 youth. The researcher stratified undergraduate students in each university and proportionately selected random samples. According to Creswell (2009), stratified sampling produces are more inclusive because they incorporate sub-groups of small populations, which researchers are likely to leave out if they employ other sampling procedures.

\section{Study Sample}

Undergraduate students at Kenya Methodist University were divided according to three schools: School of Education \& Social Sciences (SESS), School of Business and Economics (SBE) and School 
of Medicine, Health Sciences \& Technology (SMHST) while students at Africa International University were divided according to School of Theological Studies (STS), School of Business and Economics (SBE) and School of Education Arts \& Social Sciences (SEAS). Table 1 provides a summary of the samples drawn from the universities.

Table 1. Sample Summary

\begin{tabular}{|c|c|c|c|c|c|c|c|c|}
\hline \multirow[t]{2}{*}{ Universities } & \multirow[t]{2}{*}{ Population } & \multicolumn{7}{|c|}{$\begin{array}{c}\text { Sample } \\
\text { per School }\end{array}$} \\
\hline & & STS & Sample & SEAS & Sample & SBE & Sample & Totals \\
\hline \multirow[t]{2}{*}{ AIU } & 680 & 207 & 76 & 255 & 94 & 220 & 82 & 252 \\
\hline & & SMHS & & SESS & & SBE & & \\
\hline KeMU & 566 & 163 & 67 & 157 & 65 & 246 & 102 & 234 \\
\hline Total & 1,246 & 370 & 143 & 377 & 147 & 501 & 196 & 486 \\
\hline
\end{tabular}

\section{Research Tools}

The researcher used a self-developed questionnaire with five-point rating scale: strongly agree, agree, not sure, disagree and strongly disagree. The content validity of the 64-item questionnaire was determined by four research experts while its reliability was determined through Cronbach's alpha which gave a reliability coefficient of 0.83 . The reliability of the interview guide was determined through pilot testing.

\section{Data Gathering}

With permission from National Commission for Science, Technology \& Innovation (NACOSTI), the researcher personally distributed 486 questionnaires. Out the distributed questionnaires 417 were correctly filled and returned. The researcher also conducted face-to-face interviews with 10 key informants to comprehensively explore the why and how of accidental lessons. The researcher met all the key informants, and after explaining the aims of the research, she invited each of them to participate in the face-to-face interviews. Each interviews lasted close to 40 minutes.

\section{Data Treatment}

Data was analysed using descriptive and Pearson correlation statistics in the SPSS program version 25 program. The descriptive statistics determined frequency of respondents' views on the Likert scales while Pearson correlation coefficient and Analysis of Variance tested the relationships between independent and dependent variables. The researcher also conducted Regression coefficient to determine combined effect of the accidental messages arising from learning institution's organizational structure, interrelationships, instructional models, and cultural inclinations on students' ways of thinking, and professionalism development. 
The grounded theory analysis approach was utilized in analysing the textual data because it was perceived as offering a more neutral view of informants' experiences with the phenomenon and its influences on their behaviour.

\section{FINDINGS AND DISCUSSION}

Out of the 486 administered questionnaires, 417 questionnaires were returned and determined suitable for analysis. The remaining 69 questionnaires were not returned. Scholars like Morton et al. (2012) argued that questionnaire response rates are informative, but on their own, they are not enough evidence to judge study quality and/or validity. All the same, low response rates indicate a potentially greater risk of low validity. In line with this observation, Creswell (2009) among other researchers suggested 60 percent or more response rate is preferable in social research. Based on the above observations, a response rate of 86 percent garnered in current research, as summarize in table 3, was considered an excellent response rate.

Table 3. Questionnaires return rate

\begin{tabular}{lll}
\hline Response Rate & Frequency & Percent \\
\hline Questionnaires given out & 486 & 100 \\
Questionnaires returned & 417 & 86 \\
Spoiled/not returned questionnaires & 69 & 14 \\
\hline Total & 486 & $\mathbf{1 0 0}$ \\
\hline
\end{tabular}

\section{Respondents' gender}

The results from item 1 which asked respondents to indicate their gender indicated that a large proportion of the respondents 212 (50.8\%) were male while 179 (42.9\%) were female. 26 (6.2\%) of the respondents who filled and returned the questionnaire did not indicate their gender. Figure 1 summarizes the findings.

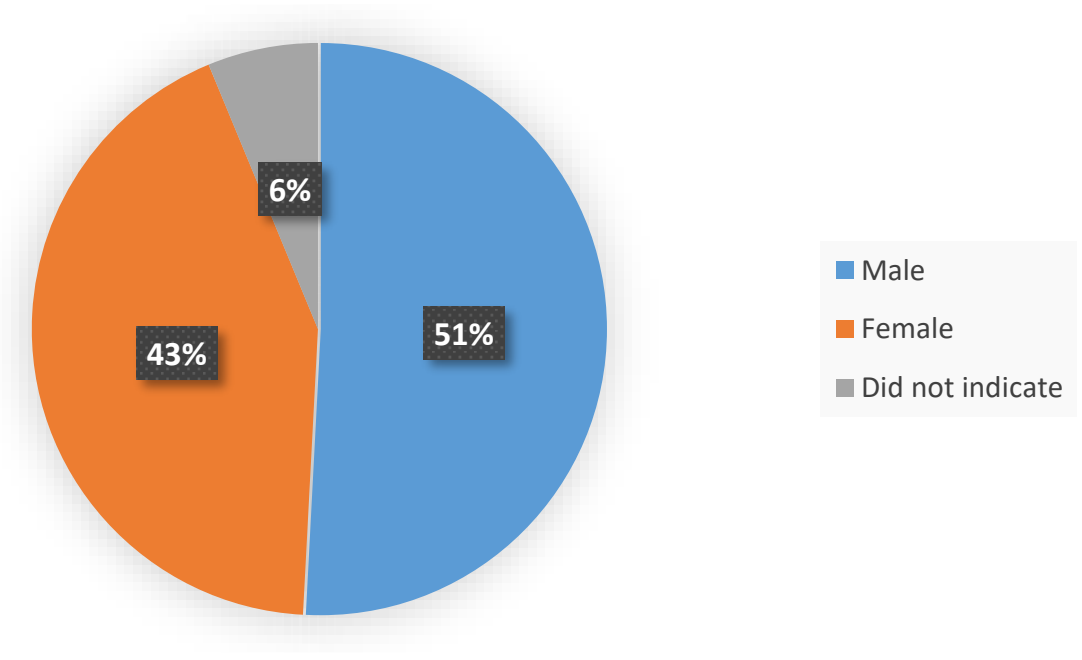

Figure 1. Respondents' gender 
The results on item 2 which asked respondents to indicate their age bracket indicated that a large proportion of the respondents 220 (52.8\%) were aged $25-35$ years, $68(16.3 \%)$ were aged 17 years and below, 60 (14.4\%) were aged 36-45 years, $42(10.1 \%)$ were aged 46 years and above while only $6(1.4 \%)$ were aged $18-24$ years. The results also indicated that $21(5 \%)$ of the respondents who filled and returned the questionnaire did not indicate their age bracket. Figure 2 provides summary of the findings.

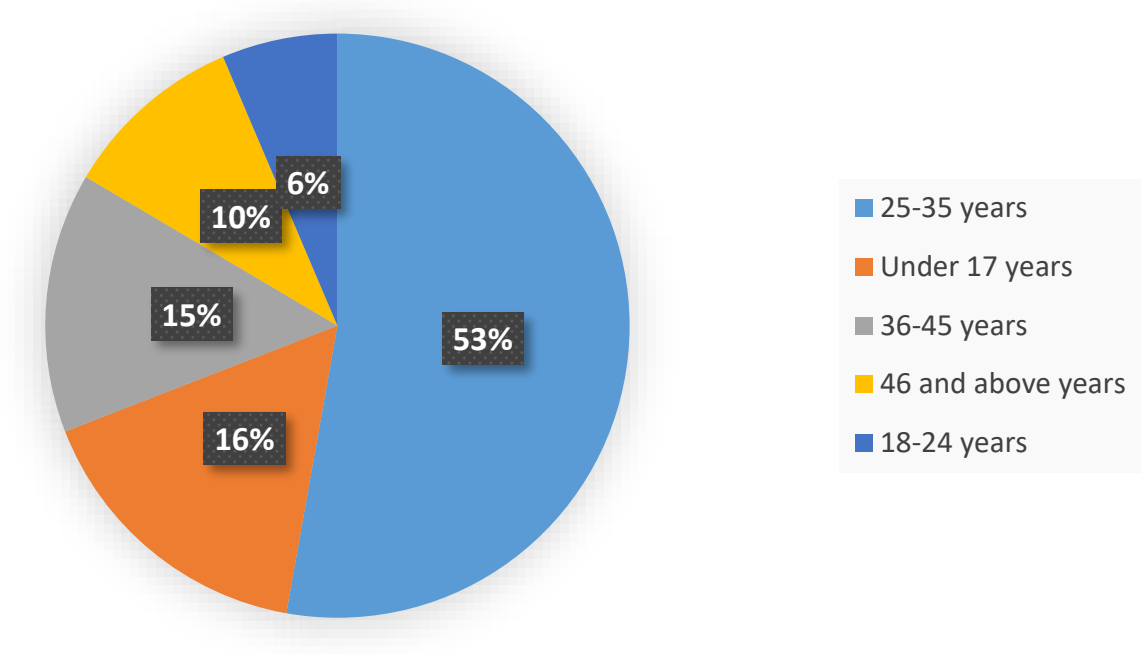

Figure 2. Respondents' age

The results from item 3 which asked respondents to indicate the number of courses they had taken on-line indicated that 189 (45.3\%) of the respondents had done very few on-line courses, 77 (18.5\%) indicated that they had done few on-line courses, 41 (9.8\%) had done an average number of courses on-line, 22 (5.3\%) indicated that they had done a good number of on-line courses while $88(21.1 \%)$ of the respondents did not indicate the number of courses they had done online. A summary of the findings is provided in Figure 3.

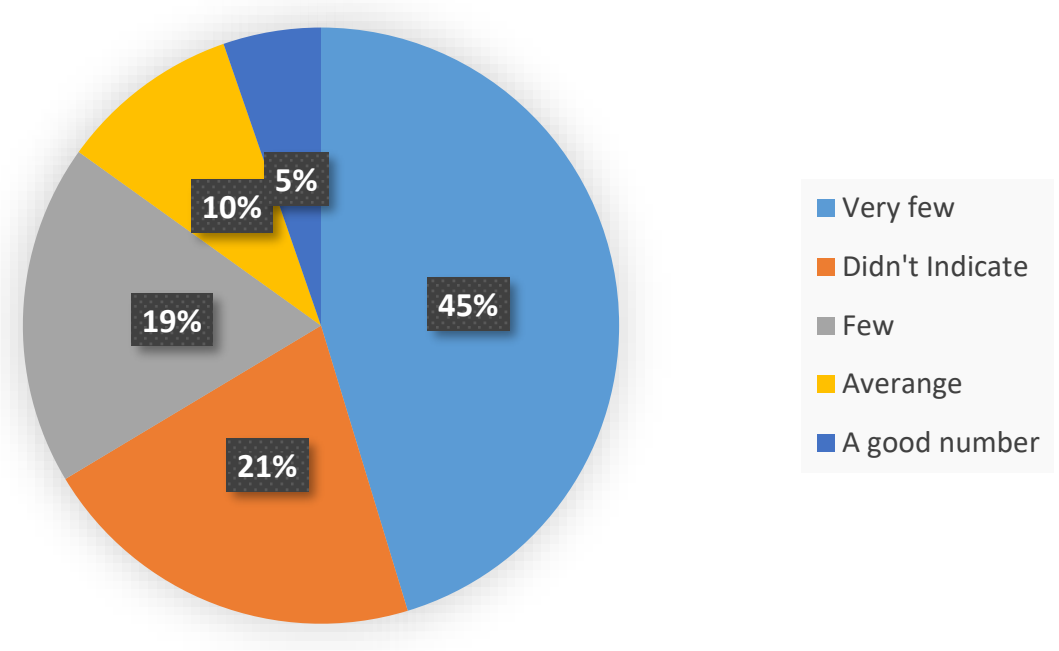

Figure 3. Courses done online 
The results from item 4 which asked respondents to indicate their area of study indicated that $44(10.3 \%)$ of the respondents were pursuing theological studies. $165(42.2 \%)$ of the respondents were pursuing business and economics studies. 71 (18.2\%) of the respondents were in the school of education, arts, and social sciences. 38 (9.7\%) were pursuing counselling psychology while $46(11.8 \%)$ of the respondents indicated that they were doing information technology. A small percentage 27 (6.9\%) of the respondents who filled and returned the questionnaire indicated that they were in other schools while $26(6.2 \%)$ of the respondents did not indicate their area of study. Table 2 provides a summary of the findings.

Table 2. Students' area of study

\begin{tabular}{llcc}
\hline & & & Valid \\
Category & Frequency & Percentage & \\
\hline Theological studies & 44 & 10.6 & 11.3 \\
Business and Economics & 165 & 39.6 & 42.2 \\
School of education Arts and Sciences & 71 & 17.0 & 18.2 \\
Counselling Psychology & 38 & 9.1 & 9.7 \\
Information Technology & 46 & 11.0 & 11.8 \\
Other & 27 & 6.5 & 6.9 \\
Sub-total & 391 & 93.8 & 100.0 \\
No Response & 26 & 6.2 & \\
& & & \\
\hline Total & 417 & 100 & \\
\hline
\end{tabular}

\section{$H_{01}$ : There is no significant relationship between students' demographics and their perceptions regarding how accidental lessons arising from learning institutions' secreted curriculum influences their ways of thinking and behaviour.}

A Pearson coefficient correlation analysing conducted to test hypothesis 1: students' demographics have no significant influence on their perceptions regarding how learning institutions' hidden curriculum influences their ways of thinking, revealed a significant relationship between students' demographics and their perceptions regarding how secreted messages arising from the hidden curriculum influences their ways of thinking and their professional behaviour like honesty and integrity, accountability, self-regulation and compassion/empathy. Table 4 provided a summary of the findings. 
Table 4. Correlation analysis on students' demographics' influences

\begin{tabular}{|c|c|c|c|c|c|c|}
\hline & & $\begin{array}{l}\text { Students' } \\
\text { worldview }\end{array}$ & Gender & Age & $\begin{array}{l}\text { Courses } \\
\text { done } \\
\text { online }\end{array}$ & $\begin{array}{l}\text { School } \\
\text { of } \\
\text { Study }\end{array}$ \\
\hline Students' & Pearson & & & & & \\
\hline \multirow[t]{3}{*}{ worldview } & Correlation & 1.000 & & & & \\
\hline & Sig. (2-tailed) & & & & & \\
\hline & Pearson & & & & & \\
\hline \multirow[t]{3}{*}{ Gender } & Correlation & $.151^{*}$ & 1.000 & & & \\
\hline & Sig. (2-tailed) & 0.012 & & & & \\
\hline & Pearson & & & & & \\
\hline \multirow[t]{2}{*}{ Age } & Correlation & $.143^{*}$ & 0.085 & 1.000 & & \\
\hline & Sig. (2-tailed) & 0.017 & 0.096 & & & \\
\hline \multicolumn{7}{|c|}{$\begin{array}{l}\text { Courses done } \\
\text { online Pearson }\end{array}$} \\
\hline & Correlation & -0.057 & -0.012 & $.132 *$ & 1.000 & \\
\hline & Sig. (2-tailed) & 0.384 & 0.83 & 0.017 & & \\
\hline School & of Pearson & & & - & & \\
\hline \multirow[t]{2}{*}{ Study } & Correlation & $-.170 * *$ & -0.089 & 0.065 & 0.053 & 1.000 \\
\hline & Sig. (2-tailed) & 0.005 & 0.085 & 0.206 & 0.341 & \\
\hline
\end{tabular}

* Correlation is significant at the 0.05 level (1-tailed).

** Correlation is significant at the 0.025 level (2-tailed).

As indicated in table 4 respondents' gender $(r=0.151 ; p=0.012)$ and age $(r=0.143$, $p=0.017$ ) had a significant positive influence on students' perceptions regarding how secreted curriculum influences ways of thinking, and professional behaviour like honesty and integrity, accountability, self-regulation, trustworthiness, and compassion/empathy. The study program respondents were pursuing was revealed as having a significant negative $(r=-.170 * * p=0.005)$ influence on the respondents' ways of thinking and professional behaviour like honesty and integrity, accountability, self-regulation, and compassion/empathy. The results on the number of on-line courses respondents had taken revealed a lack of significant influence $(p=0.384)$ on respondents' perceptions regarding how the secreted curriculum influences their ways of thinking, and professional behaviour. The results led to the rejection of null hypothesis 1.

$H_{02}$ There is no significant relationship between accidental lessons arising from learning institutions' organizational structure on students' ways of thinking and behaviour.

A univariate analysis the researcher conducted to test null hypothesis 2 indicated a positive and significant relationship between secreted messages arising from learning institutions' organizational structure and students' ways of thinking, and professional behaviour like honesty 
and integrity, accountability, self-regulation, and compassion. The coefficient of determination also known as the $R$ squared produced a $p$ value of 0.000 , which was less than the conventional probability of 0.05 for a one tailed test, as summarized in table 5 , suggested that secreted messages arising from learning institutions' organizational structure have a significant influence on students' ways of thinking, and their professional behaviour.

Table 5. Analysis of variance

\begin{tabular}{llllll}
\hline Indicator & Sum of Squares & Df & Mean Square & $F$ & Sig. \\
\hline Regression & 65.227 & 1 & 65.227 & 999.480 & $0.000^{\text {b }}$ \\
Residual & 21.014 & 322 & .065 & & \\
\hline Total & $\mathbf{8 6 . 2 4 1}$ & 323 & & & \\
\hline
\end{tabular}

Table 6 presents the regression of coefficients results, which indicated a positive and significant relationship between unintended lessons arising from learning institutions' organizational structure and students' ways of thinking, values, and professional behaviour as supported by a $p$ value of 0.000 and a beta coefficient of 0.87 which was greater than the critical $t$ statistics of 1.96. The results suggested mapping learning instructions' organizational structure with positive elements of the secreted curriculum would improve students' ways of thinking and their professional behaviour with respect to commitment to work, adherence to virtues like honesty and integrity, accountability, self-regulation, trustworthiness, and compassion/humanism.

Table 6. Regression of Coefficients

\begin{tabular}{lllllll}
\hline Model & & \multicolumn{2}{l}{$\begin{array}{l}\text { Unstandardized } \\
\text { Coefficients } \\
\text { Std. } \\
\text { B }\end{array}$} & $\begin{array}{l}\text { Standardized } \\
\text { Coefficients }\end{array}$ & T & Sig. \\
\hline 1 & 0.189 & 0.077 & & Beta & & \\
\hline & $\begin{array}{l}\text { (Constant) } \\
\text { Organizational } \\
\text { structure }\end{array}$ & $\mathbf{0 . 9 1 9}$ & $\mathbf{0 . 0 2 9}$ & $\mathbf{0 . 8 7}$ & $\mathbf{3 1 . 6 1 5}$ & $\mathbf{0 . 0 0 0}$ \\
\hline
\end{tabular}

Regression coefficient

Dependent variable-students' worldview

The specific model.

$Y=\beta 0+\beta 1 X 1+e$

Student's worldview $=0.189+0.87$ Christian universities' organizational structure 
$H_{03}$ : There is no significant relationships between accidental lessons arising from learning institutions' interrelationships students' ways of thinking and behaviour.

A univariate analysis the researcher conducted to test hypothesis 3 indicated a positive and significant relationship between accidental messages arising from learning institutions' social interrelationships and young peoples' ways of thinking and their professional behaviour like honesty and integrity, accountability, self-regulation, trustworthiness, and compassion. The coefficient of determination also known as the $R$ square produced a $p$ value of 0.000 which was less than the conventional probability of 0.05 for a one tailed test, as summarized in table 7 , which led to the rejection of null hypothesis 3 .

Table 7. Analysis of variance

\begin{tabular}{llllll}
\hline Indicator & Sum of Squares & Df & Mean Square & $F$ & Sig. \\
\hline Regression & 78.291 & 1 & 78.291 & 1180.354 & $.000^{\text {b }}$ \\
Residual & 24.143 & 364 & .066 & & \\
\hline Total & $\mathbf{1 0 2 . 4 3 4}$ & 365 & & & \\
\hline
\end{tabular}

The regression coefficients results presented in table 7 indicated a positive and significant relationship between secreted messages arising from social interrelationships and students' ways of thinking, and their professional behaviour like honesty and integrity, accountability, self-regulation, trustworthiness, and compassion. A p-value of 0.000 and a beta coefficient of 0.874 which was greater than the critical t statistics of 1.96 , which suggested enhancing positive interrelationships in learning institutions is likely to positively influence students' ways of thinking, and their professional behaviour with respect to honesty and integrity, accountability, self-regulation, trustworthiness, and compassion.

Table 8. Regression coefficient

\begin{tabular}{lllllll}
\hline \multirow{2}{*}{ Model } & & \multicolumn{2}{l}{ Unstandardized } & \multicolumn{2}{l}{ Standardized } & \\
& & Coefficients & Coefficients & T & Sig. \\
& & B & Std. Error Beta & & \\
\hline 1 & (Constant) & .389 & .068 & & 5.681 & .000 \\
& Social Interrelationships & .887 & .026 & .874 & 34.356 & .000 \\
\hline
\end{tabular}

Dependent Variable: Students' Worldview

The specific model.

$Y=\beta 0+\beta 1 \times 1+e$

Student's worldview=0.389+0.874 Christian universities' social interrelationships. 
$H_{04}$ : there are no significant differences between fluences of unintended lessons arising from learning institutions on-ground and on-line instructional models on students' ways of thinking and behaviour.

A univariate analysis conducted to test null hypothesis 4, indicated that there was no significant difference between influences of accidental lessons arising from learning institutions' onground and the influences of accidental lessons arising from on-line instructional models on students' ways of thinking, and their professional behaviour like honesty and integrity, accountability, self-regulation, trustworthiness, and compassion. The coefficient of determination also known as the $\mathrm{R}$ square produced a $\mathrm{p}$ value of 0.000 which was less than the conventional probability of 0.05 for a one tailed test, as summarized in table 9 , which led to the rejection of null hypothesis 4.

Table 9. Analysis of variance

\begin{tabular}{llllll}
\hline Indicator & Sum of Squares & Df & Mean Square & $F$ & Sig. \\
\hline Regression & 82.141 & 1 & 82.141 & 550.010 & $.000 \mathrm{~b}$ \\
Residual & 50.777 & 340 & .149 & & \\
& & Total & $\mathbf{1 3 2 . 9 1 8}$ & & \\
\hline
\end{tabular}

The regression coefficient results presented in table 10 indicated a positive and significant relationship between accidental messages arising from learning institutions' instructional models and students' ways of thinking, and their professional behaviour like honesty and integrity, accountability, self-regulation, trustworthiness, and compassion/humanism. A p-value of 0.000 and a beta coefficient of 0.786 which was greater than the critical $t$ statistics of 1.96, which suggested ensuring each instructional model is mapped with positive elements of the hidden curriculum would positively shape young people's ways of thinking and their professional behaviour with respect to commitment to work, honesty and integrity, accountability, self-regulation, trustworthiness, and compassion. 
Table 10. Regression coefficient

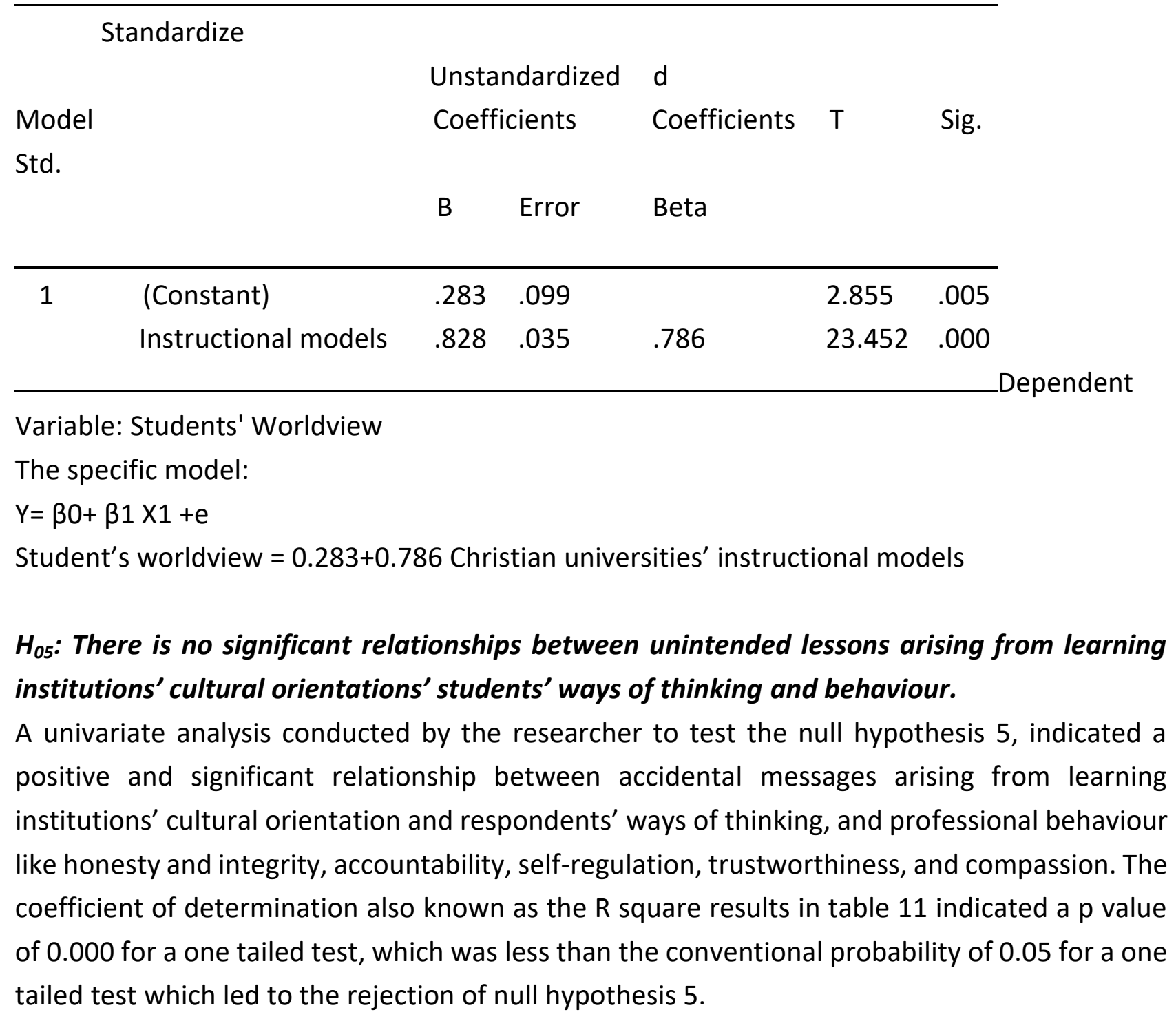

Table 11. Analysis of variance

\begin{tabular}{llllll}
\hline Indicator & Sum of Squares & Df & Mean Square & F & Sig. \\
\hline Regression & 289.292 & 1 & 289.292 & 1173.228 & $.000 \mathrm{~b}$ \\
Residual & 83.343 & 338 & .247 & & \\
\hline Total & $\mathbf{3 7 2 . 6 3 5}$ & $\mathbf{3 3 9}$ & & & \\
\hline
\end{tabular}

The regression coefficients results presented in table 12 indicated a positive and significant relationship between learning institutions' cultural orientations and respondents' ways of thinking, and their behaviour. A p value of 0.000 and a beta coefficient of 0.881 which was greater than the critical t statistics of 1.96 which suggested ensuring positive cultural inclination in learning institutions would positively impact respondents 'ways of thinking, and 
their professional behaviour with respect to commitment to work, honesty and integrity, accountability, self-regulation, trustworthiness, and compassion.

Table 12. Regression coefficient

\begin{tabular}{lllllll}
\hline Model & & \multicolumn{2}{l}{$\begin{array}{l}\text { Unstandardized } \\
\text { Coefficients }\end{array}$} & $\begin{array}{l}\text { Standardized } \\
\text { Coefficients }\end{array}$ & T & Sig. \\
& & $\begin{array}{l}\text { Std. } \\
\text { B }\end{array}$ & Error & Beta & & \\
& & & & & & \\
\hline 1 & (Constant) & -.163 & .101 & & -1.607 & .109 \\
& Cultural Orientations & $\mathbf{1 . 0 6 6}$ & .031 & .881 & $\mathbf{3 4 . 2 5 2}$ & .000 \\
\hline
\end{tabular}

a. Dependent Variable: Students' Worldview

The specific model.

$\mathrm{Y}=\beta 0+\beta 1 \mathrm{X} 1+\mathrm{e}$

Student's worldview $=-0.163+0.881$ Christian universities' Cultural Orientations

A multiple regression analysis conducted to determine the strength of collective influence of the accidental messages arising from the four independent sources of hidden curriculum elements, indicated a positive and significant correlation between the respondents' ways of thinking, and their professional behaviour and the accidental messages. The beta coefficients and $p$ values in table 13 was less than the conventional $p$ value of 0.05 for a one tailed test. The implication here is that accidental lessons arising from learning institutions' organizational structure including rules regarding time allocation, social interrelationships, instructional strategies employed as well cultural orientations have a subliminal effect that significantly influences students' ways of thinking, and ultimately their professional behaviour like honesty and integrity, accountability, self-regulation, trustworthiness, and compassion/humanism either negatively or positively.

Table 13. Regression coefficient

\begin{tabular}{llllll}
\hline & \multicolumn{2}{l}{$\begin{array}{l}\text { Unstandardized } \\
\text { Coefficients }\end{array}$} & $\begin{array}{l}\text { Standardized } \\
\text { Coefficients }\end{array}$ & T & Sig. \\
& B & Std. Error & Beta & & \\
\hline (Constant) & 0.228 & 0.082 & & 2.766 & 0.006 \\
Organizational structure & 0.163 & 0.029 & 0.178 & 5.608 & 0 \\
Social Interrelationships & 0.281 & 0.028 & 0.327 & 9.91 & 0 \\
Instructional models & 0.196 & 0.022 & 0.272 & 8.716 & 0 \\
Cultural Orientation & 0.265 & 0.017 & 0.469 & 15.389 & 0 \\
\hline
\end{tabular}

Dependent Variable: Students Worldview 
The optimal model for the study was: students' worldview $=0.228+0.178$ accidental lessons arising from learning institutions' organizational structure +0.327 social interrelationships +0.272 instructional models +0.469 cultural orientation.

The qualitative data generally concurred with the quantitative data. For instance, 9 participants out of the 10 who were interviewed claimed that the secreted curriculum was more important compared to the official curriculum in determining students' leaning outcomes. The interviewed participants also claimed that secreted curriculum lessons are ingrained in learning institutions' organizational structure, cultural inclinations, instructional strategies, and social interrelationships and neither curriculum planners nor teachers could purport to be very familiar with the secreted lessons students imbibe by just setting their feet in a learning context. Participants 02, 06, 09 and 10 indicated that unspoken messages conveyed through evaluation strategies in learning contexts which emphasize the importance of students getting into instructors' heads and reproducing its content pertaining to taught course content during exam, were detrimental to student's critical thinking and problem-solving skills which are key elements of true professionalism. Participant 03 echoed the same sediments when he or she asserted that "unintended lessons conveyed through cherished values in learning contexts like how instructors relate with students significantly shape young people's knowledge acquisition styles, their view of self and reality in general including their professional identity. Participant 04 suggested that if educators would thoroughly understand the accidental messages conveyed through learning institutions' social atmosphere including how teachers evaluate students' learning, especially evaluation strategies that encourage competition when success of some groups or individual students is showcased, then they are likely to positively restructure such important activities to positively influence students' professional values such as honesty and integrity, accountability, self-regulation, trustworthiness, and compassion/humanism.

When the researcher probed the participants on why they perceived the highlighted aspects as having significant influence on their learning experiences, the 10 participants claimed that learning social atmosphere is crucial on the kind of young people turn out to become. Participant 05 asserted "the first day I entered the university classroom, the social emotional environment of the classroom immediately separated me from my high school world." When the researcher prompted on what the participant meant by university's classroom social emotional atmosphere "separating him from his high school world," he said; "entering the university's learning context seems to create open doors before students and I think it immediately begins to grow one up academically, emotionally, and professionally". In the same vein, participant 01 asserted "when classroom setup is in harmony with the values a teacher cherishes and his or her teaching style, the benefits are endless, including encouraging students to be active creators of knowledge instead of being passive receivers."

In relation to on-line and on-ground learning experiences' influences on students' attitudes and ways of thinking, the 10 participants suggested that some students in purely online classes struggle in consistently displaying upright moral values like honesty and integrity, 
accountability, self-regulation, and trustworthiness. This is because as highlighted by participants 01,03 and 08 , there is a great likelihood for students in on-line class to justify actions based on what they see in mass media as opposed to the intrinsic good such actions have. Participant 03 explained that compared to on-ground learning settings where lecturers share their lives with students, in on-line settings there is limited lecturer-student interactions which sometimes negatively shape students' professional values. These observations are in harmony with researchers like Fyock (2008), Crossman's (2019) and Mei (2015) who argued that the moral character of teachers influence students' moral values development both positively and negatively. The findings also concur with Rogers et. al (2012) research findings which revealed that secreted lessons arising from casual interactions as well as how businesses are conducted in social contexts influence young people's ways of thinking, attitude, and values such as honesty and integrity, accountability, self-regulation, trustworthiness, and compassion/empathy. Participant 09 echoed the same sentiments when she asserted:

Young people rarely talk about powerful lectures they had on professionalism. They mostly talk about role models and mentors-of faculty members and older peers who demonstrated to them what it means to live morally upright lives. Mentors may not even be aware they are perceived as so by young people and those aware of being perceived as good models may believe that they are always positively mentoring but may sometimes mentor in the reverse direction as professional values permeate through the cracks of the official curriculum.

According to participants 03,07 and 10 any society that desires to see more morally upright societies, it must ensure its learning contest provide a viable framework for appraising the secreted curriculum and its effects on professional behaviour of present and future doctors, layers, politicians, teachers, faith leaders and at the same time minimize effects of negative secreted curriculum elements. According to participant 02 and 05 powerful lectures on commitment to work, humility, honesty and integrity, accountability, self-regulation, trustworthiness, and compassion/humanism have limited results, if any. Instead, educator should demonstrate such professional values and young people will catch them.

\section{CONCLUSION}

This article makes key contributions to existing literature on curriculum studies research and professional identity formation. The results of the research showed that accidental lessons arising from the secreted curriculum, especially role models' cultural inclinations, can either reinforce and enhance professionalism or hinder its development, particularly when a learning context does not display upright professional values that young people are expected to demonstrate like respect, honesty, and compassion. According to these findings, the best solution to negative influences of secreted curriculum is to be cognizant of it, map its positive elements into the official curriculum, and intentionally develop approaches of mitigating its negative impact. Even though some accidental messages arising from the secreted curriculum 
may present a huge challenge to professionalism education, they also provide openings to help redesign learning institutions' socio-cultural atmosphere. Current researcher believes if professional values are intentionally mapped in the official curriculum and demonstrated, a good number of young people are likely to catch them because professional values are more caught than taught. On the contrary unconducive social learning contexts which convey negative secreted messages are likely to continue hindering the effective nurture of morally upright professionals, whom contemporary world craves for.

\section{REFERENCES}

Abroampa, W. K. (2020). The hidden curriculum and the development of latent skills: The praxis. Journal of Curriculum and Teaching, 9(2), 70-77.

https://doi.org/10.5430/jct.v9n2p70

Barani, G., Fereydoon, A. \& Seyyed, H. S. (2011). Quality indicators of the hidden curriculum in centres of higher education. Procedia - Social and Behavioral Sciences, 30, 1657-1661. https://doi.org/10.1016/i.sbspro.2011.10.321

Bayramlı, T. (2018). The role of hidden curriculum in schooling. Retrieved from https://eduonline.az/2018/09/03/the-role-of-hidden-curriculum-in-schooling/

Chandratilake, M. N. \& de Silva N. R. (2009). Identifying poor concordance between the 'planned' and the 'hidden' curricula at a time of curriculum change in a Sri Lankan medical school. South East Asian Journal of Medical Education, 3(2), 15-19.

Chowdhury, M. (2016). Emphasizing morals, values, ethics, and character education in science education. The Malaysian Online Journal of Educational. 4(2), 1-16.

Covey, S. R. (1990). Seven deadly sins as per Mahatma Gandhi. Retrieved from https://www.mkgandhi.org/mgmnt.htm

Creswell, J. W. (2009). Research design: Qualitative, quantitative, and mixed methods approach ( $3^{\text {rd }}$ Ed.). Thousand Oaks: Sage Publications Inc.

Creswell, J. W. \& Clark, V. L. P. (2011). Designing and conducting mixed-methods research. Thousand Oaks: Sage Publications.

Crossman A. (2019). What is the hidden curriculum? ToughtCo, Retrieved From https://www.thoughtco.com/hidden-curriculum3026346

Çubukçu, Z. (2012). The effects of secreted curriculum on character nurture process of primary school youths. Educational Consultancy and Research Centre. 12(2), 1526-1534.

Denisov, A. (2017). What millennials are lacking: Soft skills. Retrieved from https://www.linkedin.com/pulse/what-millennials-lacking-soft-skills-anatoly-denisov/

Dewey, J. (1938). Experience and education. New York: The Macmillan company. 
Doja, A., Dylan B., Chantalle C., Marc Z. \& Hilary W. (2018). Observations of the hidden curriculum on a paediatrics tertiary care clinical teaching unit. Paediatrics \& Child Health, 23(7), 435-440. https://doi.org/10.1093/pch/pxx206

Donohue, D.K. (2021). Culture, cognition, and college: How do cultural values and theories of intelligence predict students' intrinsic value for learning? Journal of Culture and Values in Education, 4(1). https://doi.org/10.46303/jcve.2020.3

Drew, C. (2021). What is hidden curriculum? Retrieved from https://helpfulprofessor.com/hidden-curriculum/

Eisner, E. (2002). The educational imagination: On the design and evaluation of school programs (4 $\left.{ }^{\text {th }} \mathrm{Ed}\right)$. New York: Macmillan.

Evetts, J. (2009). Changing teacher professionalism: International trends, challenges, and ways forward. Oxon: Routledge.

Fyock, J. A. (2008). The effect of the teacher's worldviews on the worldviews of high school seniors. [Doctoral Dissertation, School of Education Liberty University, Lynchburg, VA]. Retrieved from $\underline{\text { https://digitalcommons.liberty.edu/cgi/viewcontent.cgi?article=1113\&context }=\mathrm{d}}$ octoral

Garcia, E. (2014). The need to address noncognitive skills in the education policy agenda. EPI briefing paper no. 386. Retrieved from https://files.eric.ed.gov/fulltext/ED558126.pdf

Glicken, A. D. \& Gerald B. M. (2009) Addressing the hidden curriculum: Understanding educator professionalism. Medical Teacher, 29(1), 54-57.

https://doi.org/10.1080/01421590601182602

Habibu, B. (2020). Ibrahim Magu's Saga: A nation starving of morally upright leaders. Retrieved from https://www.ripplesnigeria.com/ibrahim-magus-saga-a-nationstarving-of-morally-upright-leaders/

Hafferty, F. W \& Franks R. (1994). The hidden curriculum, ethics teaching, and the structure of medical education. Academic Medicine, 69(11): 861-71. https://doi.org/10.1097/00001888-199411000-00001

Hafferty F. W. (1998). Beyond curriculum reform: Confronting medicine's hidden curriculum, Academic Medicine, 73(4), 403-407. https://doi.org/10.1097/00001888-199804000-00013

Hafferty, F. W., Elizabeth H. G. \& Joseph F. O'D. (2015). The role of the hidden curriculum in "on doctoring" courses. AMA Journal of Ethics, 17(2): 129-137. https://doi.org/10.1001/virtualmentor.2015.17.2.medu1-1502

Howieson, W \& Cloke, D. (2019). The hidden curriculum and its implications for surgical specialties. The Bulletin, 101(7), 282-284.

https://doi.org/10.1308/rcsbull.2019.282 
Hubbard, B. (2010). Manifestations of hidden curriculum in a community college online opticianry program: An ecological approach. [Doctoral Dissertation, University of South Florida). https://digitalcommons.usf.edu/etd/1660/

Hundert, E. M., Hafferty, F. \& Christakis, D. (1996). Characteristics of the informal curriculum and trainees' ethical choices. Academic Medicine. 71(6):624-633. https://doi.org/10.1097/00001888-199606000-00014

Jerald, C. D. (2006). School culture: The hidden curriculum. Retrieved from https://www.readingrockets.org/article/school-culture-hidden-curriculum

Karimi, Z., Tahereh A., Easa M. \& Heidar A. A. (2014). Curriculum to Teach Professionalism in Nursing Student. Iranian Red Crescent Medical Journal, 16(3): 15532. https://doi.org/10.5812/ircmj.15532

Keaton, A. F. (2017). Teaching students the importance of professionalism. Retrieved from https://www.facultyfocus.com/articles/effective-classroommanagement/teaching-students-importance-professionalism/

Killick, D. (2016). The role of the hidden curriculum: Institutional messages of inclusivity. Journal of Perspectives in Applied Academic Practice, 4(2), 20-24. https://doi.org/10.14297/ipaap.v4i2.203

Lehmann, L., Lois S. S. \& Sanjay D. (2018). Hidden curricula, ethics, and professionalism: optimizing clinical learning environments in becoming and being a physician. $A$ position paper of the American college of physicians. 168(7), 506-508. https://doi.org/10.7326/M17-2058

Lempp H. \& Seale C. (2004). The hidden curriculum in undergraduate medical education: Qualitative study of medical students' perceptions of teaching, BMJ. 329, 770773. https://doi.org/10.1136/bmj.329.7469.770

Massialas, B. \& Hurst, J. (2009). The new social studies-retrospect and prospect. The Social Studies, 100(6), 246-250. https://doi.org/10.1080/00377990903351424

Mei, P. (2015). The hidden curriculum in language classrooms. Sino-US English Teaching, 12(6), 424-429. https://doi.org/10.17265/1539-8072/2015.06.003

Merriam-Webster's Collegiate Dictionary Eleventh Edition. (2002). Merriam Webster Inc. Morgan, K. (2017). Surprising authorship of "The Great Want of This Age." Retrieved from http://advindicate.com/articles/2017/10/30/surprising-authorship-of-thegreat-want-of-this-age

Morton, S, Dinusha, B., Elizabeth, R., Polly E. \& Atatoa, C. (2012) In the $21^{\text {st }}$ Century, what is an acceptable response rate? Australian and New Zealand Journal of Public Health, 36(2), 106-108. https://doi.org/10.1111/j.1753-6405.2012.00854.x

Parihar, R., Poonam P. \& Devendra J. S. (2018). Declining of ethics and moral values in present scenario-an analysis. International Journal of Current Microbiology and Applied Sciences, 7(9), 1085-1092. https://doi.org/10.20546/ijcmas.2018.709.129 
Pasha, L. (2018). 69 Famous Aristotle quotes that are full of wisdom. Retrieved from https://succeedfeed.com/aristotle-quotes/

Patenaude, J., Theo, N. \& Diane, F. (2003). Changes in students' moral development during medical school: A cohort study. Canadian Medical Association Journal. 68(7), 840-4.

Porcupile, D. W. (2015). What is professionalism? What does professionalism mean to you? Retrieved from http://graduate.auburn.edu/wpcontent/uploads/2016/08/What-is-PROFESSIONALISM.pdf

Priestley, M. (2019). Curriculum: Concepts and approaches. Impact, retrieved from https://impact.chartered.college/article/curriculum-concepts-approaches/

Raghubir, A. E. (2018). Emotional intelligence in professional nursing practice: A concept review using Rodgers's evolutionary analysis approach. International Journal of Nursing Sciences, 5, 126-130. https://doi.org/10.1016/j.ijnss.2018.03.004

Roig-DeBellis, K. (2014). The importance of learning a social curriculum. Retrieved from https://www.huffpost.com/entry/the-importance-of-learnin 1 b 4455595

Rogers, D. A., Margaret L., Boehler R. N., Nicole K. R., Victoria J. (2012). Using the hidden curriculum to teach professionalism during surgery clerkship. Journal of Surgical Education, 69(3), 423-427. https://doi.org/10.1016/j.jsurg.2011.09.008

Rowland, J. (2014). Length of school year: Number of instructional days/hours in the school year. Retrieved from https://www.ecs.org/clearinghouse/01/15/05/11505.pdf

Ruff, C. S. (2013). Perspectives on the hidden curriculum within the social studies. [M.Ed. Thesis, Ohio University]. Retrieved from https://www.coursehero.com/file/27534631/MRP-RUFF-FINALpdf/

Safari Y. K. A. \& Tohidnia M. R. (2020). The hidden curriculum challenges in learning professional ethics among Iranian medical students: A qualitative study. Advances in Medical Education and Practice 11, 673-681.

https://doi.org/10.2147/AMEP.S258723

Sager, M. (2013). Understanding the Hidden Curriculum: Connecting teachers to themselves, their students, and the earth. Retrieved from https://pdxscholar.library.pdx.edu/cgi/viewcontent.cgi?article=1006\&context=Ise comp

Shaw, P. (2006). Training to failure, training to success: The hidden curriculum of seminary education. Euro-Asian Theological Journal, 84-100.

Shorten, A. \& Smith, J. (2017). Mixed methods research: expanding the evidence base. Evidence-Based Nursing, 20(3),74-75. https://ebn.bmj.com/content/ebnurs/20/3/74.full.pdf

van Kessel, C. \& Muna S. (2020). Fighting the plague: 'Difficult' knowledge as sirens' song in teacher education. Journal of Curriculum Studies Research, 2(2), 1-20. https://doi.org/10.46303/jcsr.2020.7 
Vazhathodi, S. H. (2013). Transformative value-based education: characterizing the curriculum and pedagogy of teacher training. International Conference on Teacher Education in the Muslim World 2013, Nov 12, 2013 - Nov 14, 2013, Kuala Lumpur, Malaysia.

Verma, G. (2019). The importance of a positive learning environment. https://www.linkedin.com/pulse/importance-positive-learning-environmentgeeta-verma/

Vivanco, L. \& Roberto D. (2015) Professionalism. Encyclopedia of Global Bioethics. https://doi.org/10.1007/978-3-319-05544-2 353-1

Wiggins, G. \& McTighe, J. (2004). The understanding by design professional development workbook. Alexandria: Association for Supervision and Curriculum Development

Yousefzadeh, M. (2014). The role of elements of hidden curriculum in learning life skills among university students: A case study of the students at Islamic Azad University. Indian Journal of Fundamental and Applied Life Sciences, 4(4), 34033409.

Yüksel, S. (2006). The role of hidden curriculum on the resistance behaviour of undergraduate students in psychological counselling and guidance at a Turkish University. Asia Pacific Education Review, 7(1), 94-107. https://doi.org/10.1007/BF03036788 